\title{
PERILAKU PEMBELIAN MELALUI INTERNET
}

\author{
Ibnu Widiyanto ${ }^{1 *}$, Sri Lestari Prasilowati ${ }^{2}$ \\ ${ }^{1}$ Fakultas Ekonomika dan Bisnis Universitas Diponegoro \\ Jalan Prof. Soedarto SH, Tembalang, Semarang 50238, Indonesia \\ ${ }^{2}$ Sekolah Tinggi Ilmu Ekonomi IPWIJA, \\ Jalan Letda Natsir No.7, Gn. Putri, Bogor 16967, Indonesia \\ * Penulis Korespondensi; E-mail: ibnu.widiyanto@undip.ac.id.
}

\begin{abstract}
Abstrak
Penelitian ini dirancang untuk menyelidiki atribut web perilaku pembelian online. Beberapa variabel disusun untuk membangun sebuah model yaitu kemenarikan desain website, reputasi vendor, persepsi kemudahan transaksi, sikap belanja online. Pengaruh keempat variabel tersebut kemudian diuji terhadap keputusan pembelian online. Populasi penelitian ini adalah mereka yang pernah membeli online pada jaringan Indonesia dan digunakan sendiri. Besarnya sampel adalah 100 responden. Studi ini menyimpulkan bahwa keputusan pembelian online paling besar dipengaruhi oleh kemenarikan desain website dan reputasi vendor. Pengaruh sikap terhadap keputusan pembelian online tidak signifikan meskipun bertanda positif. Namun demikian, persepsi kemudahan transaksi signifikan memengaruhi sikap. Studi ini merekomendasikan pengembangan reputasi vendor dan kemenarikan desain website untuk mendorong keputusan pembelian online.
\end{abstract}

Kata kunci: Belanja online, desain website, reputasi, kemudahan transaksi, sikap

\begin{abstract}
This research was designed to investigate web attributes of online buying behavior. Some variables were developed to establish a model, namely web design attractiveness, vendor reputation, perceived ease of transaction, attitudes towards online buying. The variables effects were then tested on online purchase decision. The population was people who purchased via online on Indonesian webs and for their own uses. The sample sizes were 100 respondents. The study concluded that online purchase decision was mostly influenced by web design attractiveness and vendor reputation. Unfortunately the influence of attitude on online purchase was insignificant, although its sign was positive. However, perceived ease of transaction significantly affected attitudes. It recommended development of better vendor reputation and web design attractiveness to stimulate online purchase decision.
\end{abstract}

Keywords: Online buying, web design, reputation, perceived ease of transaction, attitude

\section{Pendahuluan}

Pengelola bisnis dewasa ini sebaiknya senantiasa memfokuskan perancangan strateginya pada bagaimana melayani dan mempertahankan pelanggan (Best, 2013). Oleh karenanya, pengelola bisnis perlu melakukan antisipasi kebutuhan pelanggan dan penyesuaian produk maupun fitur produk sesuai keinginan pelanggan. Dalam konteks inilah, penerapan strategi bisnis harus berorientasi pada pemanfaatan dan aplikasi metode-metode guna menarik perhatian, pemeliharaan retensi pelanggan serta meningkatkan dan mengelola hubungan antara prinsipal dengan pelanggan. Bahkan metode yang digunakan diharapkan mulai berbasis teknologi.

Persaingan bisnis saat ini telah mendorong para pengelola bisnis (maupun calon pelaku bisnis) untuk bergerak cepat, kreatif dan antisipatif. Hal ini disebabkan oleh perubahan mendasar dalam sistem persaingan bisnis yang memanfaatkan teknologi. Perubahan tersebut meliputi sistem perdagangan, cara bertransaksi, sistem pemasaran maupun sistem pembayaran. Adanya berbagai kesepakatan tentang perdagangan bebas (misalnya ATIGA maupun APEC) telah mengakibatkan berbagai produk mengalir dengan deras dari satu negara ke negara lain tanpa hambatan ataupun proteksi yang berarti. Masuknya produk-produk dari Cina ke Indonesia ternyata tidak mampu dicegah oleh otoritas perdagangan Indonesia. Cara mengenalkan produk pun sekarang ini cenderung menggunakan metode direct marketing yang memang telah didukung oleh teknologi informasi yang super canggih. Produk dengan cepat dapat ditawarkan kepada para prospective buyer langsung ke meja mereka. Ini dikarenakan 
pengomunikasian produk sekarang sudah menggunakan media teknologi informasi terutama media internet yang langsung ke para pembeli potensial.

Kesesuaian produk dengan kebutuhan pelanggan dan prospek memiliki peran sangat sentral pada masa penetrasi pasar, baik untuk meraih pasar sendiri, akuisisi pelanggan pesaing, maupun dari pasar baru. Pelayanan menjadi pemeran utama untuk mempertahankan pasar yang sudah diraih (customer retention). Oleh karena itu, strategi produk tanpa ditopang oleh strategi pelayanan akan menyebabkan seolaholah prestasi pemasaran baik tetapi sebenarnya performance perusahaan secara keseluruhan tidak menguntungkan. Sebaliknya strategi pelayanan yang baik tanpa didukung oleh produk yang baik akan menjadikan partumbuhan pasar yang lambat.

Selain untuk menopang strategi pemasaran sendiri, ketepatan strategi dalam produk dan layanan juga mampu meningkatkan brand equity, sehingga performance perusahaan dari sisi awareness, image, satisfaction dan loyalty menjadi baik. Kekuatan brand equity-lah yang membedakan performance jangka panjang dan jangka pendek. Brand dengan short term performance yang bagus tetapi tidak memiliki brand equity, maka long term performance-nya belum dapat terjamin. Perusahaan dengan short term performance yang bagus dan brand equity yang baik, maka dapat dipastikan bahwa dalam jangka panjang perusahaan ini akan mampu mempertahankan keunggulannya.

Dari sisi konsumen, baik buruknya atau tinggi rendahnya brand equity tersebut akan menyebabkan baik buruknya sikap konsumen atas merk yang ada. Untuk ini, Pavlou dan Gefen (2002) serta Xu dan Yadav (2003) menjelaskan bahwa baik buruknya reputasi akan mengurangi atau meningkatkan kekhawatiran konsumen manakala membeli suatu produk. Ini sebenarnya berkaitan dengan rasa percaya seseorang manakala akan membeli suatu produk. Oleh karenanya, pengelola bisnis perlu untuk memelihara kebaikan brand equity (baik dari reputasi maupun dari sisi beban merk) agar calon konsumen selalu percaya dan tidak khawatir manakala mengkonsumsi suatu produk. Cara lain untuk menjaga brand equity adalah dengan meningkatkan Coporate Social Responsibility (Niazi, Haider, Islam, \& Rehman, 2012).

Dalam era globalisasi saat ini, proteksi pemerintah atas suatu industri menjadi suatu hal yang niscaya. Semua usaha apapun bentuknya haruslah bersiap diri untuk menghadapi persaingan baik potensial (karena adanya entry barrier) maupun aktual (antar produk) agar mampu mempertahankan kelangsungan hidupnya. Beberapa penelitian seperti Doyle (2000) menunjukkan bahwa produsen perlu mempelajari atribut nilai pelanggan yang bisa dipakai untuk menyusun kebijakan pemasaran di masa mendatang.
Keaveney (1995) menambahkan beberapa alasan pindah pemasok dalam bisnis jasa. Alasan tersebut meliputi harga (seperti harga mahal dan kenaikan harga), ketidaknyamanan (seperti lokasi dan waktu pelayanan), kegagalan pelayanan (seperti tidak sopan, tidak peduli), kesalahan pelayanan (seperti salah tagihan), tanggapan terhadap kesalahan pelayanan (seperti tanggapan negatif), persaingan (seperti ada pesaing yang lebih baik), masalah etika (seperti berbohong, konflik kepentingan), alasan pindah lainnya (seperti pelanggan pindah dan penyedia jasa bangkrut).

Pertumbuhan teknologi informasi yang sangat pesat telah menciptakan peluang bisnis baru dalam mengejar kesuksesan usahanya. Teknologi internet, misalnya, telah menjadikan bisnis saat ini menjadi borderless dan timeless (tanpa batas wilayah dan tanpa batas waktu). Menurut penelitian Nucifora (2000), omzet bisnis di tahun 2003 diperkirakan sekitar 3,2 triliun dollar, sedangkan menurut Statistic Brain (2015), penjualan online global di tahun 2011 sudah tercatat 763 trilliun dollar. Dengan lebih dari 2,4 milyar pengguna di media 2012, ini menunjukkan bahwa penggunaan internet sebagai prasarana bisnis sangat menjanjikan.

Sementara itu, Indonesia termasuk satu negara yang mengalami booming pengguna di internet. Jika pada tahun 1998, pengguna internet hanya tercatat sekitar 500 ribu saja, di awal dekade abad 21 ini terjadi lonjakan yang cukup tinggi yaitu sekitar 61 juta pengguna internet (Karimuddin, 2012). Banyaknya pengguna internet inilah telah menempatkan Indonesia sebagai negara terbesar keempat yang mengakses internet. Gambar 1 menunjukkan posisi pengguna internet di Asia (sekitar 44\% dari dunia).

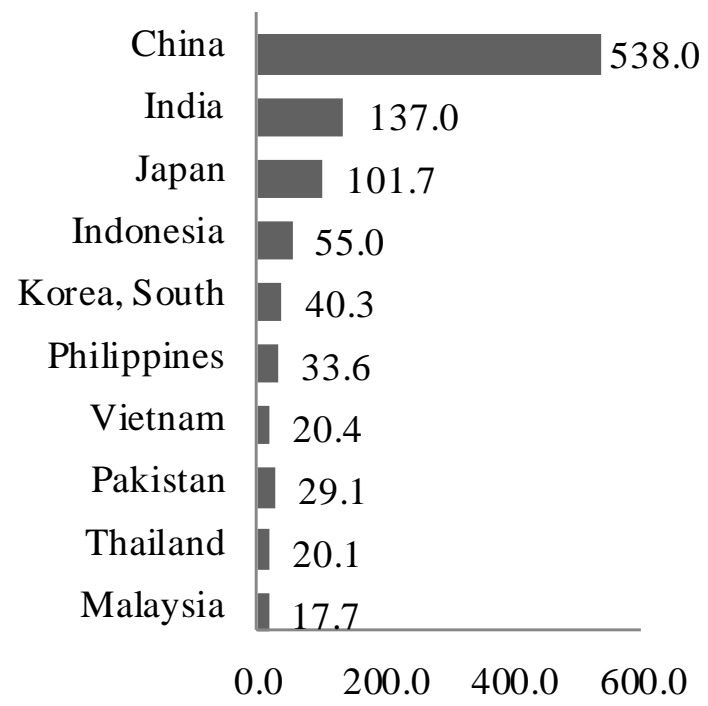

Gambar 1. Asia Top Internet Countries

Sumber: www.internetworldstats.com 
Sementara itu, Lichtenthal dan Eliaz (2003) menyebutkan bahwa sistem komunikasi business online adalah satu-satunya cara yang mampu mengirimkan pesan kepada pelanggan yang paling lengkap seperti awareness, knowledge, liking, preference, conviction dan purchase. Sistem komunikasi lainnya tidak mampu mengaksentuasi selengkap sistem komunikasi online ini. Oleh karenanya tidak mengherankan kalau para pengelola bisnis sekarang mulai merambah untuk menawarkan produk bisnisnya secara online.

Perkembangan bisnis online di Indonesia selain cukup pesat juga sangat menjanjikan. Hampir semua sektor bisnis saat ini telah menggunakan internet sebagai media transaksi. Di sektor perbankan, hampir semua bank (kecuali BPR) mulai mengandalkan otomasi transaksi seperti penggunaan ATM maupun internet banking. Di sektor jasa transportasi udara, semua perusahaan airline telah menggunakan sistem booking/reservasi online dalam mendukung transaksi bisnisnya. Bahkan lembaga sekuritas lokal pun juga mulai menyediakan fasilitas transaksi online sebagai sarana pendukung transaksi jual beli sahamnya. Semakin menguatnya penggunaan media online inilah yang menyebabkan perilaku konsumen dan perilaku bisnis saat ini dan masa mendatang akan mengalami perubahan yang cukup ekstrim (Wolfinbarger \& Gilly, 2003).

Sementara itu, Turban, King, Lee, \& Viehland (2004) menjelaskan bahwa dengan semakin banyaknya dan semakin mudahnya fasilitas internet, belanja online menjadi tren baru yang terasa lebih sederhana, efisien dan cepat tanpa ditemui hambatan bisnis yang berarti. Biaya transportasi dan waktu berbelanja terasa akan sangat menjadi lebih hemat dan lebih efektif. Belanja online akhirnya menjadi salah satu gaya hidup di Indonesia.

Namun, berbelanja secara online juga memiliki banyak risiko. Turban et al. (2004) kemudian menambahkan paling tidak ada lima risiko yang dihadapi para pembeli online. Risiko pertama adalah ketidaksesuaian produk yang dipesan dengan gambar yang ditampilkan. Ini umumnya terjadi karena gambar display selain sudah direkayasa juga sering di"sengaja" ditampilkan secara khusus dengan tampilan warna yang lebih menggoda. Risiko kedua adalah rusaknya barang yang diterima. Rusaknya barang ini selain mungkin karena rusak dalam pengiriman juga karena cacat produksi. Risiko ketiga adalah kesalahan dalam pengepakan yang akan memunculkan kesalahan order baik berupa warna, jumlah maupun tipe. Risiko keempat adalah tidak terkirimnya barang karena hilang/terlambat. Adanya pemogokan buruh di sektor transportasi udara di tahun 2010/2011, telah menyebabkan sebuah perusahaan pengiriman kargo terkena klaim dari konsumennya. Risiko kelima adalah munculnya fraud atau penipuan. Umumnya yang mengalami risiko ini adalah pihak penjual. Oleh karenanya, untuk meminimalisir risiko yang ada pihak penjual maupun pembeli perlu melakukan tindak yang lebih berhati-hati misalnya mengecek sekuritas bisnis online yang ada.

Berdasarkan uraian di atas terlihat faktor yang memengaruhi seseorang melakukan pembelian sangat beragam. Adi (2013) menyebutkan kemenarikan posting messages dan reputasi memengaruhi minat seseorang dalam melakukan pembelian online. Sementara Shim, Shin, \& Nottingham (2002) menjelaskan bahwa perilaku pembeli online sangat bergantung pada ketersediaan informasi, kemenarikan desain website dan kemudahan dalam melakukan transaksi online. Keberadaan faktor tersebut akan memengaruhi sikap seseorang atas web yang menawarkan transaksi online. Sikap inilah yang nantinya mengakibatkan keputusan seseorang dalam melakukan pembelian online. Oleh karenanya, dalam penelitian ini rumusan masalah yang diajukan adalah "Bagaimana membangun atribut web pembelian online." Pertanyaan penelitian yang diajukan dalam penelitian ini adalah apakah terdapat pengaruh kemenarikan desain website, reputasi vendor dan persepsi kemudahan transaksi terhadap sikap terhadap belanja online? Apakah terdapat pengaruh sikap belanja online terhadap keputusan belanja online? Apakah sikap belanja online terbukti sebagai intervening variabel dari pengaruh kemenarikan posting messages, reputasi dan persepsi kemudahan transaksi terhadap keputusan belanja online?

\section{Belanja Online}

Turban et al. (2004), Katawetawaraks dan Wang (2011) menjelaskan bahwa belanja online adalah kegiatan pembelian produk (baik barang ataupun jasa) melalui media internet. Kegiatan belanja online meliputi kegiatan Business to Business (B2B) maupun Business to Consumers (B2C). Sementara pada penelitian kegiatan belanja online dikaitkan dengan B2C karena kegiatan pembelian yang dimaksudkan adalah kegiatan pembelian yang digunakan oleh konsumen sendiri, tidak dijual kembali. Kegiatan belanja online di sini adalah transaksi yang bersifat ritel dengan pembeli individu, sehingga belanja online di sini adalah sebuah keputusan pembelian yang dilakukan oleh individu secara online. Salah satu manfaat dalam belanja online adalah calon pembeli dapat melihat terlebih dahulu (produk) yang akan dibelinya melalui web yang ditawarkan oleh penjual. Kegiatan ini sering disebut dengan searching.

Kotler dan Armstong (2004) menjelaskan bahwa keputusan pembelian merupakan tindakan 
atau perilaku seseorang dalam melakukan keputusan untuk memilih suatu produk baik dari sisi jenis maupun kuantitas produk itu sendiri. Proses keputusan itu sendiri paling tidak ada lima tahapan meliputi pengenalan kebutuhan, pencarian informasi, pengevaluasian alternatif, penentuan pembelian dan perilaku pembelian yang umumnya merupakan kepuasan atas pemilihan keputusan yang diambil.

Sementara itu, Kinnear dan Taylor (1995) serta Uddin, Lopa, \& Oheduzzaman (2014) mengemukakan bahwa faktor-faktor yang memengaruhi pembelian umumnya berkaitan dengan perasaan dan emosi. Kotler dan Keller (2013) menjelaskan bahwa proses pengambilan keputusan selalu berhubungan dengan situasi yang tidak terduga dan sikap terhadap pembelian.

\section{Sikap Berbelanja Online}

Seock dan Norton (2007), Rahayuningsih (2008), Prasad dan Aryasri (2009) mengemukakan bahwa sikap merupakan suatu bentuk perasaan yang bersifat favourable atau unfavourable. Dengan demikian, sikap pada dasarnya menunjukkan kondisi mental atau pun rasionalitas tertentu yang mencerminkan suatu pandangan pribadi mengenai suatu objek ataupun konsep. Pandangan tersebut dapat berupa pandangan yang positif (bermanfaat) dan pandangan negatif (destruktif). Kim, Ferrin, \& Rao, (2008) dan Shim, Eastlick, Lotz, \& Warrington (2001) selanjutnya menjelaskan bahwa sikap belanja online di sini merupakan faktor penyebab yang sangat penting dalam proses pengambilan keputusan pembelian online.

Breckler (1984) mengidentifikasi tiga dimensi sikap yaitu dimensi kognitif, dimensi afektif dan dimensi konatif. Dimensi kognitif adalah suatu dimensi yang mengacu pada keyakinan individu terhadap suatu objek. Dimensi afektif merupakan suatu dimensi yang melibatkan perasaan oleh stimulus dari dalam hati individu. Sementara itu, dimensi konatif berkaitan dengan kecenderung seorang individu berperilaku atas suatu objek. Sikap belanja online ini pada dasarnya merupakan respons seseorang atas kegiatan transaksi pembelian. Respons ini boleh jadi bersifat menguntungkan atau malah merugikan. Keller (1993) selanjutnya menambahan bahwa sikap terhadap belanja online adalah mencerminkan tanggapan (response) konsumen atas sistem belanja online yang ditawarkan. Kuat tidaknya keinginan sesorang untuk berbelanja secara online akan bergantung pada besar kecilnya manfaat yang diterima saat berbelanja secara online dibanding dengan risiko yang mungkin dialaminya (Yu \& Wu, 2007). Dari penjelasan tersebut sebuah hipotesis dapat diajukan berkaitan dengan sikap belanja online dengan kemantaban keputusan pembelian online.

$H_{l}$ : Sikap belanja online berpengaruh positif terhadap keputusan pembelian online. Semakin kuat keinginan sesorang dalam berbelanja online, semakin mantab keputusan seseorang dalam berbelanja online.

\section{Kemenarikan Desain Website}

Tidak jauh berbeda dari belanja secara offline, komunikasi pemasaran perlu juga ditampilkan secara lugas dan menarik guna membujuk calon konsumen agar berminat membeli produk yang ditawarkan. Kotler dan Keller (2013) mengemukakan bahwa salah bentuk komunikasi pemasaran adalah iklan yang harus memiliki kemenarikan khas yang mampu membuat calon konsumen tertarik pada produk yang ditawarkan. Untuk ini, fungsi iklan tersebut adalah harus mampu menginformasikan manfaat produk yang ditawarkan, memunculkan rasa percaya dan menarik hati para calon konsumen. Sebuah desain website, sebagai salah satu cara mewujudkan daya tarik iklan. Dikatakan menarik apabila isi dan tampilannya mampu menarik pasar sasaran mampu menarik minat para clickers dalam akun tersebut.

Sarwono dan Prihartono (2012) mengemukakan bahwa teknik yang memudahkan akses dan publikasi informasi adalah menggunakan interaksi sosial melalui sosial media. Diseminasi informasi melalui sosial media selain mulai menjamur karena tingginya ikatan sosial dari pengguna juga merupakan cara baru yang lebih efektif dalam pencarian informasi. Dalam penyebaran informasi inilah, kemenarikan desain website menjadi salah satu pemandu yang handal guna mendorong calon konsumen untuk mengunjungi akun yang ada. Oleh karenanya semakin menarik desain website diharapkan mampu memantabkan keputusan berbelanja online. Selain itu kemenarikan desain website akan memengaruhi keinginan seseorang dalam melakukan belanja online. Keinginan tersebut merupakan perwujudan dari kepercayaan seseorang atas transaksi yang dilakukan. Oleh karenanya, sebuah hipotesis dapat diajukan yaitu:

$\mathrm{H}_{2}$ : Kemenarikan desain website berpengaruh positif terhadap keputusan pembelian online. Semakin menarik desain website yang ditampilkan akan semakin menguatkan keputusan belanja online yang dilakukan.

Dalam melakukan belanja online, Sonja and Ewald (2003) mengemukakan bahwa, manakala seseorang ingin melakukan belanja online pastilah terbersit suatu keraguan akan risiko yang mungkin diterima. Bahkan Mayer, Davis, dan Schoorman (1995) 
berpendapat besar kecilnya keyakinan seseorang dalam berbelanja online adalah tergantung bagaimana seseorang mampu mengawasi dan mengendalikan transaksi yang dilakukan. Mukherjee dan Nath (2003) menambahkan bahwa komitmen konsumen dalam berbelanja online umumnya berkaitan dengan shared value yaitu etika, keamanan dan privacy. Kemenarikan desain website selain akan memunculkan rasa aman bahwa pihak vendor adalah penjual yang santun juga memunculkan rasa percaya bahwa penjual akan memenuhi apa yang dijanjikan (Broekhuizen \& Huizingh, 2009). Oleh karenanya kemenarikan desain website juga akan berkaitan dengan sikap seseorang dalam berbelanja online. Dengan demikian, sebuah hipotesis baru juga dapat diajukan:

$H_{3}$ : Kemenarikan desain website berpengaruh positif terhadap sikap berbelanja online. Semakin menarik desain website semakin kuat sikap seseorang untuk melakukan transaksi pembelian online.

\section{Reputasi}

Reputasi adalah citra yang melekat pada nama dari produk atau perusahaan yang memberi kesan kuat akan nama tersebut. Reputasi merupakan suatu identitas yang merupakan akumulasi nilai yang dilakukan oleh kelompok masyarakat ataupun konsumen. Herbig, Milewics, \& Golden (1994) menyatakan bahwa reputasi cenderung mencerminkan kompetensi dan keunggulan produk atau perusahaan dibandingkan pesaingnya. Reputasi umumnya berkaitan dengan pengalaman pelanggan, pembicaraan orang maupun pemberitaan media atas produk atau perusahaan tersebut.

Xu dan Yadav (2003), Li, Browne, \& Chau (2006) menyebutkan bahwa reputasi yang berdasarkan umpan balik dapat menguatkan sikap seseorang terhadap belanja online. Penjual yang memiliki track record, umpan balik yang positif dan testimonial yang baik diharapkan mampu menguatkan sikap konsumen untuk melakukan transaksi pembelian online.

Dalam konteks transaksi online, reputasi yang baik dapat dilaku-kan dengan memberi respons yang cepat dan ramah, pengiriman barang tepat waktu, pengiriman barang sesuai order serta kemudahan mengakses (Adi, 2013). Pelayanan yang baik akan mengurangi rasa khawatir calon konsumen mengenai transaksi online yang dilakukan. Adanya ketidakpuasan konsumen ketika bertransaksi online akan sangat menyebar di media sosial. Words of mouth negatif akan semakin sering bermunculan. Jika ini terjadi reputasi produk atau perusahaan yang melakukan transaksi online akan cepat terpuruk. Reputasi negatif pada akhirnya akan memengaruhi calon konsumen untuk melakukan transaksi belanja online (Williams, 2012). Selanjutnya Xu dan Yadav (2003) serta Kim dan Ahn (2007) menyatakan bahwa reputasi selain memengaruhi sikap seseorang dalam berbelanja online juga pada gilirannya memengaruhi keputusan pembelian online. Berdasarkan uraian tersebut, sebuah hipotesis dapat diajukan, yaitu:

$\mathrm{H}_{4}$ : Reputasi berpengaruh positif terhadap sikap belanja online. Semakin baik reputasi penjual online semakin kuat sikap seseorang dalam berbelanja online.

Sementara itu, Wangenheim dan Bayon (2004) mengemukakan bahwa adanya informasi atas keberadaan suatu produk atau perusahaan akan memiliki pengaruh normatif tentang suatu produk. Jika informasi atas suatu produk ataupun perusahaan adalah menunjukkan kebaikan dari produk atau perusahaan itu, maka calon konsumen akan mempersepsikan manfaat dari suatu produk tersebut adalah tinggi. Pada gilirannya, calon konsumen akan merasa semakin mantab dengan keputusannya dalam berbelanja online. Berdasarkan argument inilah, sebuah hipotesis juga diajukan yaitu:

$H_{5}$ : Reputasi berpengaruh positif terhadap keputusan pembelian online. Semakin baik reputasi penjual online, semakin mantab keputusan seseorang dalam berbelanja online.

\section{Persepsi Kemudahan Transaksi}

Davis (1989) mengemukan bahwa persepsi kemudahan merupakan persepsi seseorang yang tidak direpotkan dengan berbagai kegiatan lain dalam melakukan transaksi. Persepsi kemudahan transaksi online mengacu pada persepsi individu akan mudahnya transaksi belanja online yang dilakukan. Dalam melakukan transaksi, calon konsumen hanya melakukan sedikit usaha, tidak terlalu ribet sehingga memudahkan calon konsumen tersebut melakukan keputusan pembelian produk melalui internet. Persepsi kemudahan transaksi tersebut dapat berupa prosedur pemesanan yang sederhana, prosedur pembayaran yang variatif dan mudah dilakukan, proses pembelian yang informatif dan menyenangkan serta proses pengiriman produk yang cepat dan tepat.

Venkatesh dan Davis (2000) dan Pikkarainen, Pikkarainen, Karjaluoto, \& Pahnila (2004) menunjukkan bahwa kemudahan inilah yang menjadi faktor penting dalam belanja online. Kemudahan ini selain mudah dioperasionalisasikan juga berkaitan dapat dikurangi usaha seseorang (baik dari segi biaya, waktu dan tenaga) dalam melakukan transaksi. Kemudahan dalam berbelanja online akan menyebabkan calon konsumen tidak mengalami kesulitan dalam berbelanja online. 
Schlosser (2003), Chiu, Lin, dan Tang (2005) serta Seock dan Norton (2007) mengemukakan bahwa sikap belanja online merupakan perasaan seseorang yang terkait dengan penilaiannya atas kegiatan transaksi yang dilakukan melalui internet. Selanjutnya, Wu (2003) dan Shen, Li, \& Demoss (2012) menambahkan bahwa suatu transaksi belanja online selain dipengaruhi oleh desain website dan reputasi juga dipengaruhi oleh kemudahan yang dapat dilakukan dalam bertransaksi. Berdasarkan argument ini sebuah hipotesis dapat diajukan yaitu:

$H_{6}$ : Persepsi kemudahan transaksi berpengaruh positif terhadap sikap belanja online. Semakin mudah pandangan seseorang atas transaksi online yang dilakukan semakin kuat sikap individu tersebut dalam berbelanja online.

Adanya manfaat yang dirasakan dalam berbelanja online ini tentunya pada gilirannya akan memengaruhi perilaku seseorang dalam berbelanja online. Konsumen akan merasa senang berbelanja secara online karena umumnya mereka menemukan berbagai kemudahan manakala melakukan transaksi secara online. Delhagen (1997), Khatibi, Haque, \& Karim (2006), Kim, Ferrin, dan Rao (2008) menambahkan bahwa adanya kemudahan dalam bertansaksi online inilah yang menjadi faktor utama dalam memutuskan berbelanja secara online. Oleh karenanya sebuah hipotesis dapat diajukan yaitu:

Tabel 1

Definisi Konseptual Variabel

\begin{tabular}{|c|c|c|c|}
\hline Nama Variabel & Definisi Konseptual & Indikator & Sumber \\
\hline $\begin{array}{l}\text { Keputusan pembelian } \\
\text { online }\end{array}$ & $\begin{array}{l}\text { Tindakan konsumen dalam } \\
\text { melakukan keputusan belanja } \\
\text { online }\end{array}$ & $\begin{array}{l}\text { 1. Mantab atas keputusan } \\
\text { 2. Cepat dalam memutuskan } \\
\text { 3. Yakin keputusan tepat }\end{array}$ & $\begin{array}{l}\text { Katawetawaraks dan Wang } \\
\text { (2011); Uddin et al. (2014) }\end{array}$ \\
\hline Sikap belanja online & $\begin{array}{l}\text { Perasaan konsumen manakala } \\
\text { melakukan belanja online }\end{array}$ & $\begin{array}{l}\text { 1. Suka dengan belanja online } \\
\text { 2. Nyaman saat melakukan } \\
\text { belanja online } \\
\text { 3. Percaya dengan kebenaran } \\
\text { proses transaksi }\end{array}$ & $\begin{array}{l}\text { Rahayuningsih (2008); } \\
\text { Prasad dan Aryasri (2009) }\end{array}$ \\
\hline $\begin{array}{l}\text { Kemenarikan desain } \\
\text { Website }\end{array}$ & $\begin{array}{l}\text { Daya tarik desain Website yang } \\
\text { diunggah dalam media online }\end{array}$ & $\begin{array}{l}\text { 1. Pesan situs mudah dipahami } \\
\text { 2. Tampilan situs menarik hati } \\
\text { 3. Perpaduan ornamen situs } \\
\text { terlihat indah }\end{array}$ & $\begin{array}{l}\text { Kotler dan Armstrong } \\
\text { (2004); Broekhuizen dan } \\
\text { Huizingh (2009) }\end{array}$ \\
\hline Reputasi vendor & $\begin{array}{l}\text { Nama baik vendor dalam } \\
\text { transaksi online }\end{array}$ & $\begin{array}{l}\text { 1. Ramai dibicarakan } \\
\text { kebaikannya } \\
\text { 2. Dikenal baik } \\
\text { 3. Punya ciri khas }\end{array}$ & $\begin{array}{l}\text { Li et al. (2006) dan } \\
\text { Williams (2012) }\end{array}$ \\
\hline $\begin{array}{l}\text { Persepsi kemudahan } \\
\text { transaksi }\end{array}$ & $\begin{array}{l}\text { Persepsi individu dalam } \\
\text { bertransaksi online }\end{array}$ & $\begin{array}{l}\text { 1. Kemudahan prosedur } \\
\text { pemesanan } \\
\text { 2. Kemudahan prosedur } \\
\text { pencarian produk } \\
\text { 3. Kemudahan prosedur } \\
\text { pembayaran }\end{array}$ & $\begin{array}{l}\text { Davis (1989) dan Shen } \\
\text { et al. (2012) }\end{array}$ \\
\hline
\end{tabular}

$H_{7}$ : Persepsi kemudahan transaksi berpengaruh positif terhadap keputusan pembelian online. Semakin mudah transaksi belanja online yang dilakukan semakin mantaplah keputusan konsumen dalam melakukan belanja online.

\section{Model Penelitian}

Berdasarkan hipotesis yang diajukan sebuah model penelitian kemudian disajikan dalam Gambar 2.

KDW adalah Kemenarikan Desain Website, RV adalah Reputasi Vendor, PKT adalam Persepsi Kemudahan Transaksi, STB adalah Sikap Belanja Online dan KBO adalah Keputusan Pembelian Online.

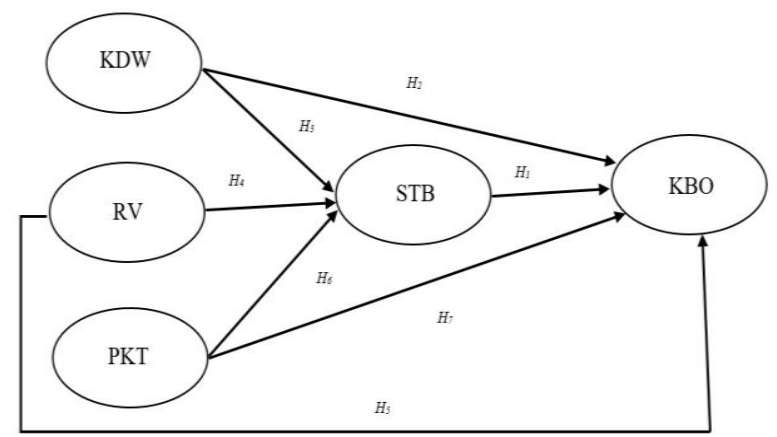

Gambar 2. Model Penelitian 


\section{Dimensionalisasi Variabel}

Penelitian sosial umumnya adalah penelitian yang bersifat persepsional. Oleh karenanya setiap variabel perlu dikembangkan dimensi ataupun indikator. Pengembangan dimensi/indikator akan berguna untuk menyusun angket. Dalam penelitian ini akan dikembangkan indikator dari setiap variabel yang bersifat refleksif. Adapun indikator tersebut disajikan pada Tabel 1.

\section{Metode Penelitian}

\section{Populasi dan Sampling Design}

Produk yang diteliti adalah produk online yang ditawarkan oleh situs dari Indonesia, misalnya produk yang ditawarkan dari berniaga.com dan tokobagus.com (sekarang dikenal sebagai situs olx.co.id) ataupun situs lain yang ditawarkan melalui media sosial. Populasi penelitian ini adalah semua orang yang pernah melakukan transaksi pembelian online pada situs yang ada. Unit analisis adalah individu dengan pembeli sebagai subjek penelitian.

Pengumpulan data pada penelitian ini menggunakan metode survei. Teknik pengumpulan data primer dilakukan dengan non-probability sampling design karena luasnya populasi penelitian. Teknik pengambilan sampel yang digunakan adalah mengkombinasi purposive sampling dan convenience sampling. Kriteria purposive sampling yaitu individu yang pernah melakukan transaksi belanja online untuk dikonsumsi/digunakan sendiri sekali dalam setahun ini. Untuk ini, angket didesain menyaring responden dengan mensyaratkan mereka harus sudah bertransaksi minimal dua kali. Karena teknik survei dilakukan secara offline, pengambilan sampel kemudian dikombinasikan dengan convenience sampling. Lokasi penelitian adalah di Kota Semarang.

Untuk memperoleh data yang diinginkan, sebuah angket ditanyakan kepada setiap responden. $\mathrm{Li}$ kert type scale dengan 10 alternatif jawaban dirancang dalam angket yang ditujukan kepada responden. Pengedaran angket dilakukan secara People-Assisted Survey. Teknik survei ini memerlukan petugas untuk menunggui setiap responden dalam mengisi angket. Manfaat teknik ini seandainya ada ketidakjelasan instrumen, petugas dapat langsung memberi penjelasan secara singkat, selain juga tingginya response rate.

Rumus yang digunakan $n=Z^{2} / 4 e^{2}$ yang mana $Z$ adalah nilai $Z$ pada derajat signifikansi tertentu dan $e$ adalah sampling error.

Penelitian ini menggunakan derajat signifikansi $5 \%$ dan sampling error $10 \%$. Oleh karenanya diperoleh $n=96,04$ dibulatkan 97. Untuk memudahkan pelaksanaan, total sampel adalah 100 responden.
Ukuran sampel ini merupakan jumlah sampel yang sudah memenuhi syarat untuk aplikasi SEM (Hair, Black, Babin, \& Anderson, 2010). Untuk ini loading factor minimal 0,6 .

\section{Teknik Analisis}

Teknik analisis yang dilakukan adalah menggunakan metode statistik deskriptif, serta metode SEM dengan software AMOS v 16.0. Melalui metode tersebut diharapkan penarikan kesimpulan dapat dilakukan secara induktif. Metode statistik deskriptif yang digunakan adalah teknik distribusi frekuensi dan nilai indeks persepsional. Skala jawaban yang digunakan 1 sampai dengan 10 , rumus perhitungan nilai indeks persepsional adalah

$$
N I=\frac{\sum_{i=1}^{10}(\% \text { FiXS } i)}{10}
$$

yang mana $N I$ adalah nilai indeks, \% Fi adalah persentase frekuensi responden yang memilih skala jawaban ke- $i, S i$ adalah skala jawaban ke- $i$ yang dipilih responden dan ke- $i$ adalah alternatif pilihan jawaban responden yang berkisar antara angka 1 sampai dengan 10. Uji intervening variabel menggunakan Sobel test.

\section{Hasil Analisis dan Pembahasan}

\section{Gambaran Umum Responden}

Responden dalam penelitian ini adalah mereka yang pernah melakukan transaksi belanja online yang dikonsumsi/digunakan sendiri dalam setahun ini. Produk online yang dibeli adalah produk yang ditawarkan oleh situs dari Indonesia. Pengedaran angket menggunakan People-Assisted-Method yakni responden dibantu dalam pengisian angket, sehingga tidak ada angket yang tidak terjawab atau kembali. Jumlah para pembeli online tersebut adalah 100 responden. Dari 100 angket ini selanjutnya dapat dirinci berdasarkan aspek demografi (jenis kelamin, usia, pendidikan dan pekerjaan) serta aspek motif pembelian (alasan dan metode pembelian).

\section{Responden Menurut Demografi}

Komposisi responden verdasarkan aspek demografi (jenis kelamin, usia, pendidikan dan pekerjaan) dapat dilihat pada Tabel 2. Tabel 2 menunjukkan bahwa karakteristik responden adalah mayoritas laki-laki berusia di bawah 36 tahun, berpendidikan di atas SMA dan memiliki pekerjaan pelajar/mahasiswa dan wiraswasta. 
Tabel 2

Responden Menurut Demografi

\begin{tabular}{lcc}
\hline \multicolumn{1}{c}{ Jenis Kelamin } & Frekuensi & Persentase \\
\hline Laki-laki & 72 & 72 \\
Perempuan & 28 & 28 \\
\hline Jumlah & 100 & 100 \\
\hline \multicolumn{1}{c}{ Usia } & Frekuensi & Persentase \\
\hline $17-25$ & 32 & 32 \\
$26-35$ & 58 & 58 \\
$36-45$ & 2 & 2 \\
46-55 & 5 & 5 \\
Di atas 55 & 3 & 3 \\
\hline Jumlah & 100 & 100 \\
\hline \multicolumn{1}{c}{ Pendidikan } & Frekuensi & Persentase \\
\hline SD/SMP & 0 & 0 \\
SMA & 10 & 10 \\
Diploma III & 30 & 30 \\
D IV/S1 & 55 & 55 \\
S2/S3 & 5 & 5 \\
\hline Jumlah & 100 & 100 \\
\hline \multicolumn{1}{c}{ Pekerjaaan } & Frekuensi & Persentase \\
\hline Pelajar/Mahasiswa & 42 & 42 \\
TNI/Polri & 2 & 2 \\
PNS/BUMN & 1 & 1 \\
Karyawan Swasta & 17 & 17 \\
Wiraswasta & 38 & 38 \\
\hline Jumlah & 100 & 100 \\
\hline
\end{tabular}

\section{Responden Menurut Jenis Produk yang Dibeli}

Adapun jenis produk yang sering dibeli secara online dapat dilihat pada Tabel 3 .

Tabel 3

Responden Menurut Jenis Produk yang Dibeli

\begin{tabular}{lcc}
\hline \multicolumn{1}{r}{ Jenis Produk } & Frekuensi & Persentase \\
\hline Peralatan Elektronik & 2 & 2 \\
Peralatan Komputer & 32 & 32 \\
Tiket Pesawat & 22 & 22 \\
Buku & 16 & 16 \\
Pakaian & 9 & 9 \\
Asesoris Mobil & 3 & 3 \\
Jasa Perbankan & 10 & 10 \\
Lainnya & 6 & 6 \\
Jumlah & 100 & 100 \\
\hline
\end{tabular}

Menurut Tabel 3 ada tiga jenis produk yang sering dibeli secara online yaitu peralatan komputer (32\%), tiket pesawat (22\%) dan buku (16\%). Jika dikaitkan dengan Tabel 2 yang menunjukkan kebanyakan pekerjaan responden adalah pelajar/mahasiswa dan wiraswasta, ketiga produk tersebut sangat terlihat berkorelasi kuat.

\section{Responden Menurut Perilaku Pembelian}

Berdasarkan data primer yang dikumpulkan melalui pengedaran angket, diperoleh alasan responden dalam melakukan pembelian online yang disajikan pada Tabel 4.
Dilihat dari perilaku pembelian online pada Tabel 4 responden adalah mereka yang telah berpengalaman dalam bertransaksi online (karena sudah melakukannya lebih dari 4 tahun) dengan metode pembayaran ATM dan pengeluaran bertransaksi sekitar Rp 500.000,- sampai dengan Rp 1.000.000,-. Alasan mereka melakukan pembelian online adalah karena proses pembelian lebih mudah dan cepat. Peralatan komputer masih merupakan produk yang paling diminati dalam pembelian online. Untuk melakukan pembelian online, handphone merupakan peralatan yang paling banyak digunakan. Tabel 4 juga menunjukkan bahwa mayoritas responden adalah mereka yang sudah lama melakukan transaksi online. Secara umum mereka sudah melakukan transaksi online setahun ke atas $(85 \%)$. Secara khusus, mayoritas responden adalah mereka yang sudah bertransaksi online di atas 4 tahun (36\%).

Tabel 4

Perilaku Pembelian Responden

\begin{tabular}{|c|c|c|}
\hline Alasan & Frekuensi & Persentase \\
\hline Harga Lebih Murah & 32 & 32 \\
\hline Lebih Mudah dan Cepat & 48 & 48 \\
\hline Lebih Banyak Pilihan & 3 & 3 \\
\hline Dapat Memilih Lebih Efisien & 6 & 6 \\
\hline Akses Informasi Lebih Banyak & 7 & 7 \\
\hline Vendor Sudah Dikenal & 4 & 4 \\
\hline Lainnya & 0 & 0 \\
\hline Jumlah & 100 & 100 \\
\hline Peralatan & Frekuensi & Persentase \\
\hline Handphone & 52 & 52 \\
\hline Laptop / PC & 32 & 32 \\
\hline Ipad / Iphone & 16 & 16 \\
\hline Jumlah & 100 & 100 \\
\hline Metode Pembayaran & Frekuensi & Persentase \\
\hline Internet Banking & 38 & 38 \\
\hline ATM & 48 & 48 \\
\hline Paypal & 2 & 2 \\
\hline Kartu Kredit & 11 & 11 \\
\hline Lainnya & 1 & 1 \\
\hline Jumlah & 100 & 100 \\
\hline Pengeluaran & Frekuensi & Persentase \\
\hline$<500.000$ & 6 & 6 \\
\hline Rp 500.000-Rp 1 juta & 74 & 74 \\
\hline$>$ Rp 1 juta-Rp 2 juta & 17 & 17 \\
\hline$>$ Rp 2 juta-Rp 3 juta & 2 & 2 \\
\hline Di atas Rp 3 juta & 1 & 1 \\
\hline Jumlah & 100 & 100 \\
\hline Lama Bertransaksi & Frekuensi & Persentase \\
\hline$<1$ tahun lalu & 15 & 15 \\
\hline 1-2 tahun lalu & 27 & 27 \\
\hline 3-4 tahun lalu & 22 & 22 \\
\hline Lebih dari 4 tahun lalu & 36 & 36 \\
\hline Jumlah & 100 & 100 \\
\hline
\end{tabular}

\section{Pengujian Validitas dan Reliabilitas Instrumen}

Pengujian validitas dilakukan dengan menggunakan metode Analisis Faktor. Perhitungan dilakukan dengan bantuan program SPSS v 16.0. Nilai loading 
factor yang berada di atas 0,193 (untuk $n=100$ ) menunjukkan sebagai indikator yang valid. Nilai Cronbach Alpha loading factor yang lebih besar dari 0,6 juga menunjukkan indikator yang reliable dalam membentuk suatu faktor. Pengujian validitas dan reliabilitas menunjukkan bahwa semua indikator dalam variabel adalah valid dan reliable.

\section{Analisis Deskriptif Jawaban Responden}

Skala pengukuran yang dilakukan dalam penelitian ini adalah menggunakan sepuluh skala pengukuran dari satu sampai dengan sepuluh. Jawaban responden yang dihasilkan akan berkisar dari 1 sampai dengan 10 dengan kriteria skala 1 sangat tidak setuju dan skala 10 sangat setuju.

Angket didesain dengan lima belas pertanyaan tertutup. Masing-masing variabel terdiri dari beberapa pernyataan yang terbagi dalam beberapa indikator. Tabel 5 dan 6 menunjukkan jumlah instrumen masing-masing variabel dan jenis pernyataan yang tertuang dalam masing-masing dimensi pernyataan.

\section{Nilai Indeks Persepsional Variabel Independen}

Adapun distribusi frekuensi jawaban responden pada variabel independen dapat dilihat pada Tabel 5. Variabel tersebut adalah kemenarikan desain website (KDW), reputasi vendor (RV) dan persepsi kemudahan transaksi (PKT).

Tabel 5 menunjukkan bahwa indikator $X_{12}$ adalah memiliki nilai indeks persepsional tertinggi $(72,0)$ disusul oleh $X_{11}$ dan $X_{13}$. Ini berarti tampilan situs dipersepsikan paling penting oleh responden dalam pembentukan variabel kemenarikan desain website (KDW). Indikator $X_{23}$ merupakan indikator tertinggi $(72,6)$ pada variabel reputasi vendor. Indikator $X_{23}$ adalah ciri khas dari situs. Ini berarti responden lebih menyukai situs memiliki ciri khas manakala mengakses sebuah situs online. Indikator $X_{33}$ merupakan indikator yang dipersepsikan tingkat kepentingannya tinggi $(64,9)$. Ini berarti kemudahan pembayaran menjadi salah satu pilihan utama dalam bertransaksi online.

Tabel 5

Distribusi Frekuensi Variabel Independen

\begin{tabular}{ccccccccccccc}
\hline Indikator KDW & $\mathbf{\% F}$ & $\mathbf{1}$ & $\mathbf{2}$ & $\mathbf{3}$ & $\mathbf{4}$ & $\mathbf{5}$ & $\mathbf{6}$ & $\mathbf{7}$ & $\mathbf{8}$ & $\mathbf{9}$ & $\mathbf{1 0}$ & Nilai Indeks \\
\hline$X_{11}$ & $\% F$ & 0 & 0 & 1 & 7 & 12 & 17 & 25 & 19 & 15 & 4 & 69,5 \\
$X_{12}$ & $\% F$ & 0 & 0 & 0 & 0 & 14 & 22 & 20 & 22 & 18 & 4 & 72,0 \\
$X_{13}$ & $\% F$ & 0 & 0 & 1 & 4 & 13 & 9 & 34 & 13 & 10 & 6 & 69,0 \\
\hline Indikator RV & $\mathbf{\% F}$ & $\mathbf{1}$ & $\mathbf{2}$ & $\mathbf{3}$ & $\mathbf{4}$ & $\mathbf{5}$ & $\mathbf{6}$ & $\mathbf{7}$ & $\mathbf{8}$ & $\mathbf{9}$ & $\mathbf{1 0}$ & Nilai Indeks \\
\hline$X_{21}$ & $\% F$ & 0 & 0 & 2 & 6 & 16 & 13 & 19 & 19 & 18 & 7 & 70,5 \\
$X_{22}$ & $\% F$ & 0 & 0 & 0 & 8 & 12 & 17 & 19 & 25 & 13 & 6 & 70,4 \\
$X_{23}$ & $\% F$ & 0 & 1 & 3 & 9 & 6 & 13 & 14 & 24 & 19 & 11 & 72,6 \\
\hline Indikator PKT & $\mathbf{\% F}$ & $\mathbf{1}$ & $\mathbf{2}$ & $\mathbf{3}$ & $\mathbf{4}$ & $\mathbf{5}$ & $\mathbf{6}$ & $\mathbf{7}$ & $\mathbf{8}$ & $\mathbf{9}$ & $\mathbf{1 0}$ & Nilai Indeks \\
\hline$X_{31}$ & $\% F$ & 0 & 0 & 2 & 18 & 16 & 15 & 21 & 13 & 13 & 2 & 63,6 \\
$X_{32}$ & $\% F$ & 0 & 0 & 6 & 11 & 14 & 27 & 17 & 16 & 6 & 3 & 62,5 \\
$X_{33}$ & $\% F$ & 0 & 1 & 1 & 8 & 16 & 23 & 25 & 18 & 5 & 3 & 64,9 \\
\hline
\end{tabular}

Catatan:

1. $\% F$ adalah persentase frekuensi jawaban responden

2. Nilai Indeks sebagaimana disampaikan pada rumus terdahulu

Tabel 6

Distribusi Frekuensi Variabel Intervening dan Dependen

\begin{tabular}{ccccccccccccc}
\hline Indikator STB & $\mathbf{\% F}$ & $\mathbf{1}$ & $\mathbf{2}$ & $\mathbf{3}$ & $\mathbf{4}$ & $\mathbf{5}$ & $\mathbf{6}$ & $\mathbf{7}$ & $\mathbf{8}$ & $\mathbf{9}$ & $\mathbf{1 0}$ & Nilai Indeks \\
\hline$Y_{11}$ & $\% F$ & 0 & 1 & 1 & 4 & 22 & 23 & 28 & 10 & 9 & 2 & 64,6 \\
$Y_{12}$ & $\% F$ & 0 & 1 & 1 & 8 & 19 & 24 & 18 & 20 & 8 & 1 & 64,4 \\
$Y_{13}$ & $\% F$ & 0 & 0 & 5 & 9 & 14 & 29 & 16 & 19 & 6 & 3 & 63,4 \\
\hline Indikator KBO & $\mathbf{\% F}$ & $\mathbf{1}$ & $\mathbf{2}$ & $\mathbf{3}$ & $\mathbf{4}$ & $\mathbf{5}$ & $\mathbf{6}$ & $\mathbf{7}$ & $\mathbf{8}$ & $\mathbf{9}$ & $\mathbf{1 0}$ & Nilai Indeks \\
\hline$Y_{21}$ & $\% F$ & 0 & 1 & 2 & 7 & 11 & 22 & 25 & 18 & 9 & 5 & 67,3 \\
$Y_{22}$ & $\% F$ & 0 & 2 & 3 & 4 & 21 & 17 & 24 & 17 & 8 & 4 & 65,2 \\
$Y_{23}$ & $\% F$ & 0 & 0 & 1 & 8 & 11 & 16 & 25 & 24 & 12 & 3 & 69,1 \\
\hline
\end{tabular}

Catatan:

1. $\% F$ adalah persentase frekuensi jawaban responden

2. Nilai Indeks sebagaimana disampaikan pada bagian metode penelitian 
Nilai Indeks Persepsional Variabel Intervening dan Dependen

Adapun distribusi frekuensi jawaban responden pada variabel intervening dan dependen dapat dilihat pada Tabel 6. Variabel tersebut adalah sikap terhadap belanja online (STB) dan kemantaban keputusan belanja online $(\mathrm{KBO})$.

Tabel 6 menunjukkan bahwa indikator $Y_{11}$ dan $Y_{12}$ memiliki nilai indeks yang hampir sama (64,6 dan 64,4). Ini berarti responden mempersepsikan hampir sama antara rasa suka dan rasa nyaman dalam berbelanja, meski rasa suka sedikit lebih tinggi. Indikator $Y_{23}$ merupakan indikator tertinggi $(69,1)$ pada variabel keputusan berbelanja online. Ini berarti responden merasa yakin bahwa keputusan yang diambil adalah tepat.

\section{Analisis SEM}

\section{Pengujian Structural Equation Modeling}

Setelah data dianalisis melalui uji validitas dan reliabilitas dan dapat dilihat bahwa masing-masing indikator dapat didefinisikan konstruk laten, maka sebuah full model Structural Equation Modeling (SEM) dapat dianalisis. Hasil pengolahan dengan bantuan software AMOS v. 16.0 ditampilkan pada Gambar 3.

Pengujian Structural Equation Modeling (SEM) dilakukan dengan dua macam pengujian yaitu ke- sesuaian model serta uji signifikansi kausalitas melalui uji koefisien estimate. Dari Gambar 3 menunjukkan bahwa hasil chi-square adalah 101,937 dengan probability 0,102. Hasil chi-square ini menunjukkan bahwa hipotesis nol yang menyatakan bahwa model sama dengan data empiris tidak biasa diterima artinya model fit. Namun demikian perlu diketahui bahwa chi-square sangat sensitif terhadap jumlah sampel (Ghozali, 2008; Hair et al, 2010).

Nilai chi-square ini akan berubah-ubah manakala jumlah data berubah. Semakin besar jumlah sampel semakin signifikan nilai chi-square. Oleh karena itu, perlu dicari ukuran model fit lain yaitu Cmindf, GFI, TLI dan RMSEA. Dari Gambar 3, Cmindf= 1.199 (di bawah 2), $G F I=0,890, T L I=0,971$ dan $R M S E A=$ 0,045. GFI secara marjinal memenuhi criteria fit yaitu 0,90. GFI 0,89 jika dibulatkan menjadi 0,90 GFI sehingga fit. TLI sudah berada pada criteria fit yang baik yaitu di atas 0,90 dan RMSEA berada di bawah 0,08 yaitu 0,045 . Ini berarti secara keseluruhan model dapat diterima dan langkah selanjutnya dapat dipakai untuk menganalisis parameter estimator (menguji hipotesis).

Pengujian hipotesis dalam model ini adalah perlu untuk menguji hipotesis nol yang menyatakan bahwa koefisien regresi secara kausalitas adalah tidak sama dengan nol melalui uji $t$ yang lazim dalam model-model regresi (Ferdinand, 2006 dan Hair et al, 2010). Tabel 7 menunjukkan hasil signifikansi Gambar 3 .

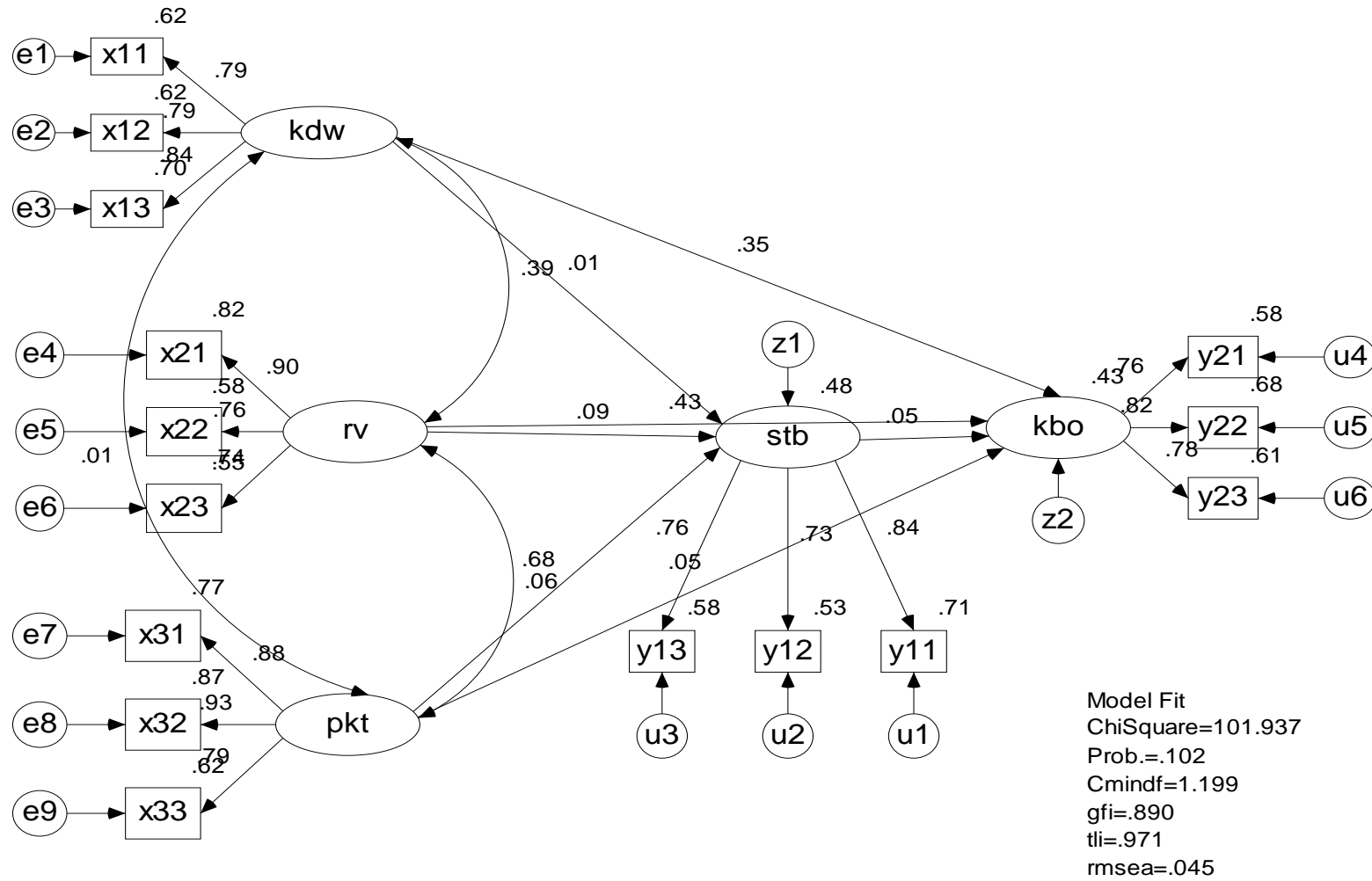

Gambar 3. Hasil Full Model SEM Empiris 
Tabel 7

Standardized Regresion Weight Structural Equation Modelling

\begin{tabular}{lccl}
\hline Hubungan Kausal & Estimate & $\begin{array}{c}\text { Critical } \\
\text { Ratio }\end{array}$ & Kesimpulan \\
\hline $\mathrm{STB} \rightarrow \mathrm{KBO}$ & 0,05 & 0,023 & $H_{1}$ ditolak \\
$\mathrm{KDW} \rightarrow \mathrm{KBO}$ & 0,35 & $2,995^{*}$ & $H_{2}$ diterima \\
$\mathrm{KDW} \rightarrow \mathrm{STB}$ & 0,01 & 0,002 & $H_{3}$ ditolak \\
$\mathrm{RV} \rightarrow \mathrm{STB}$ & 0,01 & 0,929 & $H_{4}$ ditolak \\
$\mathrm{RV} \rightarrow \mathrm{KBO}$ & 0,43 & $3,545^{*}$ & $H_{5}$ diterima \\
$\mathrm{PKT} \rightarrow \mathrm{STB}$ & 0,68 & $6,044^{*}$ & $H_{6}$ diterima \\
PKT $\rightarrow$ KBO & 0,05 & 0,011 & $H_{7}$ ditolak \\
\hline
\end{tabular}

Catatan: * signifikan $1 \%$.

Tabel 7 menunjukkan bahwa kemenarikan desain website (KDW) dan reputasi vendor (RV) berpengaruh langsung terhadap keputusan berbelanja online. Kedua variabel bertanda positif dan signifikan. Pengaruh kemenarikan desain website terhadap keputusan belanja online adalah 0,35 sedangkan besarnya pengaruh reputasi vendor terhadap keputusan belanja online adalah 0,43 . Ini berarti reputasi vendor adalah faktor yang paling berpengaruh terhadap keputusan belanja online.

Sikap terhadap belanja online lebih banyak dipengaruhi oleh persepsi kemudahan transaksi $(0,68)$. Namun demikian, ketidaksignifikanan sikap terhadap keputusan berbelanja online menunjukkan bahwa sikap bukan merupakan variabel intervening yang baik yang memengaruhi keputusan berbelanja online.

\section{Pembahasan}

Secara umum skenario model yang dapat diusulkan dalam penelitian ini adalah tampak pada Tabel 8 .

Dari Tabel 8 terlihat bahwa scenario path diagram menunjukkan bahwa studi ini mendukung bahwa keputusan belanja online dipengaruhi langsung oleh reputasi vendor dan kemenarikan desain website. Studi ini membuktikan bahwa sikap belanja online tidak mampu menjadi mediasi keputusan belanja online. Berdasarkan Sobel Test Calculator, nilai $t$ statistics ketiga variabel independen dengan intervening sikap adalah di bawah 2. Lihat Tabel 8. Ini berarti sikap bukan variabel intervening yang kuat.

Untuk ini, pebisnis online perlu lebih mengenalkan reputasi web-nya ke berbagai media. Misalnya berniaga.com, tokobagus.com dan okezone.com sudah membuktikan bahwa mereka mulai menggunakan media televisi untuk meningkatkan citra mereka. Konsep ini sekaligus dinamakan dengan across the board of campaign.
Tabel 8

Scenario Path Diagram

\begin{tabular}{lccc}
\hline \multicolumn{1}{c}{ Path Diagram } & $\begin{array}{c}\text { Path } \\
\text { Coeficient }\end{array}$ & $\begin{array}{c}\text { Sobel } \\
\text { Test }\end{array}$ & $\begin{array}{c}\text { Besaran } \\
\text { Koefisien }\end{array}$ \\
\hline $\mathrm{RV} \rightarrow \mathrm{KBO}$ & 0,43 & $\mathrm{NA}$ & 0,43 \\
$\mathrm{KDW} \rightarrow \mathrm{KBO}$ & 0,35 & $\mathrm{NA}$ & 0,35 \\
$\mathrm{PKT} \rightarrow \mathrm{KBO}$ & 0,05 & $\mathrm{NA}$ & 0,05 \\
$\mathrm{PKT} \rightarrow \mathrm{STB} \rightarrow \mathrm{KBO}$ & $0,68 * 0,05$ & 0,057 & 0,034 \\
& & $(0,955)$ & \\
$\mathrm{RV} \rightarrow \mathrm{STB} \rightarrow \mathrm{KBO}$ & $0,09 * 0,05$ & 0,318 & 0,005 \\
& & $(0,75)$ & \\
$\mathrm{KDW} \rightarrow \mathrm{STB} \rightarrow \mathrm{KBO}$ & $0,01 * 0,05$ & 0,335 & 0,0005 \\
& & $(0,738)$ \\
\hline
\end{tabular}

Keterangan:

1. NA adalah not applicable karena hanya direct effect

2. Kolom Sobel test adalah $t$ statistics pada hasil perhitungan Sobel dengan angka dalam kurung adalah probability value.

3. Sobel Test Calculator (2015) tersedia pada http://quantpsy.org/sobel/ sobel.htm.

Penelitian ini menggunakan model penelitian yang dikembangkan oleh Breckler (1984), Davis (1989), Herbig, et al. (1994), Sonja dan Edward (2003), Mukherjee dan Nath (2003), Pikkarainen et al. (2004), Li et al. (2006), Khatibi et al. (2006), Sarwono dan Prihartono (2012), dan Adi (2013). Mereka menunjukkan web attributes memiliki pengaruh langsung (direct effect) dan pengaruh tidak langsung (indirect effect) terhadap keputusan belanja online. Sayangnya penelitian ini hanya berhasil membuktikan pengaruh langsung keputusan belanja online.

Ada beberapa variabel yang perlu dipertimbangkan kembali sehingga studi tentang belanja online menjadi semakin menarik. Variabel tersebut misalnya adanya segmentasi yang lebih khusus. Karena responden penelitian ini kebanyakan laki-laki tidaklah mengherankan jika sikap tidak berpengaruh terhadap keputusan belanja. Untuk ini, keterlibatan responden secara lebih purposif terhadap gender perlu lebih diperhatikan.

Kemenarikan desain website merupakan sebuah strategi pemasaran yang handal dalam mempersuasi prospek. Desain website memang menjadi penentu dan pemikat utama dalam pengambilan keputusan. Untuk ini, tampilan display produk yang ditawarkan akan memberi daya pikat langsung yang akan menstimuli pembelian.

Secara strategik, para pemasar juga perlu senantiasa memperhatikan reputasi baik dari sisi penyedia layanan maupun reputasi produk. Sebuah produk yang sudah dipasang di situs olx.co.id tidak akan memiliki makna yang efektif manakala hanya mengandalkan satu penyedia layanan saja. Para pemasar perlu memperkuat dan menstimulasi produk yang di-dis- 
play secara online dengan media lain. Memang reputasi memiliki faktor penentu dalam perilaku pembelian. Namun reputasi tidak akan memiliki faktor determinan tinggi dalam keputusan pembelian jika gema produk yang didisplay tidak didukung dengan sarana promosi yang lain.

Berdasarkan temuan, persepsi kemudahan tranksasi mampu memengaruhi sikap belanja online meski tidak signifikan terhadap keputusan berbelanja online. Namun demikian tanda koefisien ini terhadap keputusan belanja online adalah positif. Ini artinya variabel kemudahan transaksi memiliki potensi memengaruhi belanja online.

\section{Simpulan}

Setelah melakukan survei, penelitian pembelian online ini dapat ditarik beberapa kesimpulan sebagai berikut:

1. Faktor penyebab tertinggi keputusan belanja online adalah reputasi vendor. Ini berarti perusahaan perlu melakukan banyak kegiatan above the line campaign untuk mendukung peningkatan citra bisnis. Besarnya pengaruh adalah 0,43 . Ini berarti besarnya pengaruh reputasi terhadap keputusan belanja online adalah 0,43 .

2. Faktor penyebab kedua keputusan belanja online adalah kemenarikan desain website. Ini berarti rancangan desain website perlu dibuat semenarik mungkin. Besarnya pengaruh variabel ini terhadap keputusan belanja online adalah 0,35 . Untuk ini, perancang web perlu memerhatikan untuk mengurangi/mengubah fasilitas add-on atau iklan yang banyak dilakukan agar tidak menghilangkan kemenarikan yang ada.

3. Persepsi kemudahan transaksi terbukti tidak begitu signifikan memengaruhi keputusan belanja online. Namun demikian, persepsi ini ternyata sangat memengaruhi sikap seseorang dalam belanja online. Ini berarti menunjukkan bahwa sikap bukanlah variabel intervening yang baik dalam memengaruhi keputusan belanja online.

\section{Keterbatasan dan Agenda Mendatang}

Beberapa keterbatasan pada penelitian ini diharapkan menjadi materi perbaikan yang dapat dikembangkan selanjutnya adalah sebagai berikut:

1. Penyebaran angket perlu lebih diperluas karena mencakup sistem online yang bersifat $24 / 7$ dan tanpa batas waktu dan wilayah. Sistem pengenalan responden perlu dilakukan untuk berbagai kondisi dan kedudukan di lingkungan yang beragam/ bervariasi sehingga pada saat hasil yang diperoleh dapat lebih bervariatif.

2. Pengembangan selanjutnya adalah fokus pada satu-dua situs sejenis sehingga variansi yang diperoleh tidak terlalu melebar. Penelitian ini bersifat across industry tanpa membatasi bidang/ sektor usaha yang diteliti. Tentunya variasi ini menimbulkan perbedaan sikap yang sangat jauh.

\section{Daftar Referensi}

Adi, R. N. (2013). Analisis faktor-faktor yang memengaruhi keputusan pembelian dengan sistem pre order secara online (Studi kasus pada online shop Chopper Jersey). Diunduh 19 Mei 2015 dari http://eprints.undip.ac.id/40079/ 1/ADI.pdf.

Best, R. J. (2013). Market-based management, strategies for growing customer value and profitability. New Jersey: Pearson Education, Inc.

Breckler, S. J. (1984). Empirical validation of affect, behavior, and cognition as distinct components of attitude. Journal of Personality and Social Psychology, 47 (6), 191-205.

Broekhuizen, T. \& Huizingh, E. (2009). Online purchase determinants: Is their effect moderated by direct experience? Management Research News, 32(5), 440-457.

Chiu, Y., Lin, C., \& Tang, L. (2005). Gender differs: Assessing a model online purchase intention in etail service. Journal of Service Management, 16 (5), 416-435.

Davis, F. D. (1989). Perceived usefulness, perceived ease of use, and user acceptance of information technology. MIS Quarterly, 13(2), 318-340.

Delhagen. (1997). Retailers revs up. Forester Research, 4.

Doyle, P. (2000). Value based marketing. Journal of Strategic Marketing, 8(4), 299-311.

Hair, J. F., Black, W. J., Babin, B. J., \& Anderson, R. E. (2010). Multivariate data analysis, a global perspective. New Jersey: Pearson Prentice Hall.

Herbig, P., Milewics, J., \& Golden, J. (1994). A model of reputation building and destruction. Journal of Business Research, 31(1), 23-31.

Karimuddin, A. (2012). RE: MarkPlus insight: Jumlah pengguna internet di Indonesia capai 61 juta orang. Diunduh 1 Maret 2015 dari https://dailysocial.net/post/markplus-insight-jumlah-pengguna-internet-di-indonesia-capai-61-juta-orang.

Katawetawaraks, C. \& Cheng, L. W. (2011). Online shopper behavior: Influences of online shopping decision. Asian Journal of Business Research, 1 (2), 66-74. 
Keaveney, S. M. (1995). Customer switching behavior in service industries: anexploratory study. Journal of Marketing, 59(2), 71-82.

Keller, K. L. (1993). Conseptualizing, measuring and managing customer-based brand equity. Journal of Marketing, 57(1), 1-22.

Khatibi, A., Haque, A., \& Karim, K. (2006). E-commerce: A study on internet shopping in Malaysia. Journal of Application Science, 3(6), 696-705.

Kim, M. S. \& Ahn, J. H. (2007). Management of trust in the e-market place: The role of buyer's experience in the building trust. Journal of Information Technology, 22(2), 119-132.

Kim, D. J., Ferrin, D. L., \& Rao, H. R. (2008). A trust-based consumer decision-making model in electronic commerce: The role of trust, perceived risk, and their antecedents. Decision Support Systems, 44, 544-564.

Kinnear, T. \& Taylor, J. (1995). Marketing research: An applied approach. $5^{\text {th }}$ Edition. New York: McGraw Hill.

Kotler, P. \& Armstong, G. (2004). Principles of marketing. $11^{\text {th }}$ Edition. New Jersey: Pearson Prentice Hall.

Kotler, P. \& Keller, K. L. (2013). Marketing management. $14^{\text {th }}$ Edition. New Jersey: Pearson Horizon.

Kunz, M. (1997). Online customer: Identifying store, product and consumer attributes which influence shopping on the internet. Unpublished Dissertation. University of Tennessee, Knoxville, TN.

Li, D., Browne, G., \& Chau, P. (2006). An empirical investigation of website use using a commitmentbased model. Decision Sciences, 37, 427-444.

Lichtenthal, J. D. \& Eliaz, S. (2003). Internet integration in business marketing tactics. Industrial Marketing Management, 32(1), 3-13.

Mayer, R. C., Davis, J. H., \& Schoorman, F. D. (1995). An integrative model of organizational trust. Academy of Management Review, 20(6), 709-734.

Mukherjee, A. \& Nath, P. (2003). A Model of trust in online relationship banking. International Journal of Marketing, 2l(1), 5-15.

Niazi, M. S., Haider, M. I., Islam, T., \& Rehman, S.U. (2012). The impact of corporate social responsibility on brand equity. European Journal of Social Sciences, 34, 520-529.

Nucifora. (2000). The authentic online opportunity: $\mathrm{B} 2 \mathrm{~B}$ is what you really want to be. Houson $\mathrm{Bu}$ siness Journal, 30(41), 32 A.

Pavlou, P. A. \& Geffen, D. (2002). Building effective online marketplaces with institution-based trust. Proceedings of Twenty Third International Conference on Information Systems, 667-675.
Pikkarainen, T., Pikkarainen, K., Karjaluoto, H., \& Pahnila, S. (2004). Consumer acceptance of online banking: An extension of the technology acceptance model. Internet Research, 14(30), 224 -235 .

Prasad, C. \& Aryasri, A. (2009). Determinants of shopper behavior in e-tailing: An empirical analysis. Paradigm, 13(1), 73-83.

Rahayuningsih, S. U. (2008). Psikologi Umum 2: Sikap (Online). Diunduh 1 Maret 2015 dari www .staff.gunadarma.ac.id.

Sarwono, J. \& Prihartono. (2012). Perdagangan online: Cara bisnis di internet. Jakarta: PT Media Elex Komputindo.

Schlosser, A. E. (2003). Experiencing products in the virtual world: The role of goal and imagery in influencing attitudes versus purchase intention. Journal of Consumer Research, 30(2), 184-198.

Seock, Y. K. \& Norton, M. (2007). Attitude toward internet web sites, online information search, and channel choices for purchasing. Journal of $\mathrm{Fa}$ shion Marketing and Management, 11(4), 571586.

Shen, Y., Li, S., \& Demoss, M. (2012). The effect of quantitative electronic word of mouth on consumer perceived product quality. International Journal of Management and Marketing Research. 5, 19-30.

Shim, J. P., Shin, Y. B., \& Nottingham, L. (2002). Retailer web site influence on customer shopping: An exploratory study on key factors of customer satisfaction. Journal of the Association for Information Systems, 3, 53-76.

Shim, S., Eastlick, M. A., Lotz, S. L., \& Warrington, P. (2001). An online prepurchase intention model: The role of intention to search. Journal of Retailing, 77(3), 297-416.

Sobel Test Calculator. (2015). Diunduh 1 Maret 2015 dari http://quantpsy.org/ sobel/sobel.htm.

Sonja, G. K. \& Ewald, A. K. (2003). Empirical research in online trust: A review and critical assessment. International Journal of Human-Computer Studies, 586, 783-812.

Statistic Brain. (2015). Diunduh 1 Maret 2015 dari http://www.statisticbrain.com/ total-online-sales/.

Turban, E., King, D., Lee, J., \& Viehland, D. (2004). Electronic commerce: A managerial perspective. New Jersey: Pearson Prentice Hall.

Uddin, Md. R., Lopa, N. Z., \& Oheduzzaman, Md. (2014). Factors affecting customers' buying decision of mobile phone: A study on Khulna City, Bangladesh. International Journal of Managing Value and Supply Chain, 5(2), 21-28. 
Venkatesh, V. \& Davis, F. D. (2000). A theoretical extension of the technology acceptance model: Four longitudinal field studies. Management Science, 46 (2), 186-204.

Wangenheim, F. V. \& Bayon, T. (2004). The effect of word of mouth on services switching: Measurement and moderating variables. European Journal of Marketing, 38(9/10), 11731185.

Williams, M. 2012. Relating word-of-mouth to corporate reputation. Public Communication Review, 2, 3-16.

Wolfinbarger, M. \& Gilly, M. (2003). E-tail q: Dimensionalizing, measuring and predicting etail quality. Journal of Retailing, 27, 183-198.
$\mathrm{Wu}, \mathrm{S}$. I. (2003). The relationship between consumer characteristics an attitude toward online shopping. Management Intelligence and Planning, 21 (1), 37-44.

Xu, B. \& Yadav, S. (2003). Effect of online reputetion services in electronic markets: A trust based empirical study. Ninth Americas Conference on Information Systems. Texas Tech University, Texas.

Yu, T. \& Wu, G. (2007). Determinants of internet shopping behavior: an application of reasoned behavior theory. International Journal of Management, 24(4), 744-762. 